\title{
DEVELOPMENT AND PERFORMANCE EVALUATION OF A GREENHOUSE PESTICIDE SPRAYER
}

\section{El-Ashry, A.S. ${ }^{*} \quad$ H.A. El-Gendy ${ }^{*} \quad$ M.H. Abo El-Naga* ABSTRACT}

Conditions inside the gr eenhouse are different from open field. So, the conventional sprayers, such as the self-propelled or tractor mounted boom sprayers, are not suitable for the greenhouse conditions, due to their big sizes. A disc sprayer (ultra low volume) was developed, and its performance was investigated and compared to a conventional disc sprayer and different pesticide applicator types, motorized knapsack sprayer and Hydraulic sprayer (gun). The experiments were carried out at El-Gemmieza Research Station during 2007/2008 season. The results showed that the proper unit to execute the spraying operation under greenhouse conditions is the disc sprayer after development. It has given the lowest values of volume median diameter VMD $(65 \mu \mathrm{m})$, percent of plant damage (1.26\%) and highest values of number of droplets/cm ${ }^{2}$ (295) and fungicide efficiency (86.33\%)

\section{INTRODUCTION}

7 here are over 20.000 plastic tunnels in Egypt of about $500 \mathrm{~m}^{3}$ each. These greenhouses became very important and widely

1 spread all over Egypt. Therefore, mechanization system should be applied inside these greenhouses. El-Aidy (1991) reported that in Egypt, plastic tunnel greenhouses are used increasingly as a newly developed technique for vegetable or ornamental production (about 1.000ha in 1991). Kepner et al. (1982) mentioned that the degree of atomization depends upon the characteristics and operating conditions of the atomizing device and upon characteristics of liquid being atomized.

* Senior Res., Agric. Eng. Res. Inst.(ARC), Giza. 
Roman and Beerdemeaker (1995) indicated that sprayer performance is evaluated by the uniformity of spray deposit distribution. Moustafa and Ismail (2003) studied the effect of the different fungicide applicator types on the efficacy of fungicides used to control late blight disease caused by phytophthora infestans on potato.

They found that, using the ULV applicator caused a reduction in fungicide amount needed to perform appropriate control of this disease from $400 \mathrm{~L} / \mathrm{fed}$, (the recommend amount) to $50 \mathrm{~L} / / \mathrm{fed}$. The lower amount of the fungicide run-off in turn saves the environment and decreases the crop production costs. Ismail and Badr (2004) studied the effect of applicator types on metalaxyl residue in cucumber. They concluded that using ULV applicator reduces the amount of fungicides needed to perform well control of the disease to $25 \%$ of the recommended dose and reduced the fungicide residues in the fruits. Matthews (1992) reported that the transport of the spray droplets to the target is affected strongly by weather conditions especially wind, low humidity and high temperatures, which generally reduce impaction efficiency and increase, drift. The

spinning disc atomizers are more widely used to provide greater control of droplet size, by changing the rotational speed and adjusting flow rate. Abdel-Fattah (2003) carried out a comparative study of different pest control machinery for cotton. He found that the smallest droplets were recorded with micron ULV sprayer $(85.8 \mu \mathrm{m})$ followed by Mist blower $(126 \mu \mathrm{m})$ then the Knapsack with hand lance $(161 \mu \mathrm{m})$ and the biggest droplets were recorded with spray gun of motor spray $(356 \mu \mathrm{m})$. Conditions inside the greenhouse are different from those of the open field, because the maximum height of machinery is a limiting factor for operating such machine under greenhouse. This height should be less than 2m, (El Ashry 1994). Therefore, careful attention should be paid for selecting the proper equipment to do an effective job. Therefore, the main objective of this study is improving the impaction efficiency of spinning disk sprayer and to evaluate the effect of different fungicide applicator types on the efficiency of the fungicides used in greenhouse, and their effects on spraying efficiency (droplet size spectra and spray distribution pattern), production costs and environmental pollution under greenhouse conditions. 


\section{MATERIALS AND METHODS}

To fulfill the objective of this study, three sprayer types were used to apply the recommended fungicides (Ridomil plus 50\% wp, which contains $35 \%$ copper oxychloride and $15 \%$ metalxyi) at the concentration of $300 \mathrm{~g} / 100 \mathrm{~L}$ water. The three sprayers are:-

1- Hydraulic sprayers (gun), high volume (HV), with 600liter tank, and one hollow-cone nozzle.

2- Motorized knapsack blower sprayer, low volume (LV), which consists of a $2 \mathrm{Hp}(1.47 \mathrm{~kW})$ motor, two stroke, $35 \mathrm{cc}, 6000 \mathrm{rpm}$ and air speed at outlet of about $75 \mathrm{~m} / \mathrm{s}$. blower impeller diameter: $70 \mathrm{~cm}$, hose length: $100 \mathrm{~cm}$, and liquid tank capacity: 20 liters.

3- A grooved toothed spinning disc sprayer, ultra low volume (ULV) operating with rechargeable battery, with rotation disk of about $8000 \mathrm{rpm}$.

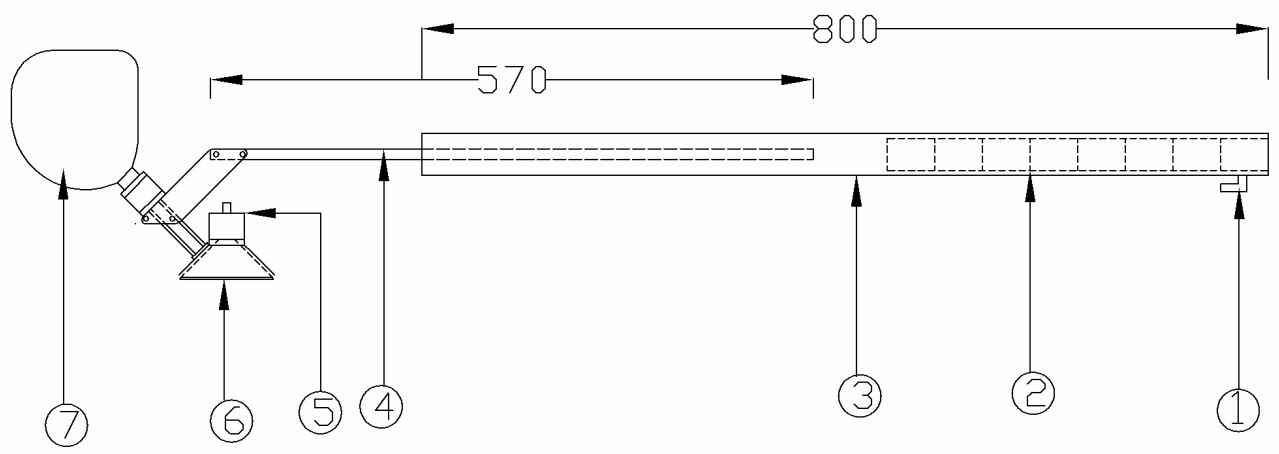

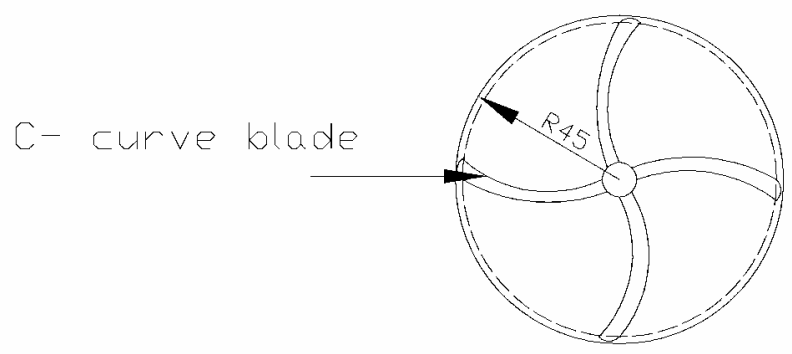

The modified disc.
1- on/off

2- 12 V Battery

3- Battery case

4- Arm

5- Motor

6- Disc

Diameter: $90 \mathrm{~mm}$

Number of blades: 4

Shape blades: $\mathrm{C}$ curve

7- Bottle

Fig. (1): Schematic diagram for modified disc sprayer. 
Cucumber var. Beita Alfa was planted on December 2006 under the greenhouse conditions in El-Ghrabeia governorate. The plants were positioned in double rows, each of width $0.80 \mathrm{~m}$ with an inter-row spacing of $0.5 \mathrm{~m}$. The plants were mainly $2.0 \mathrm{~m}$ height. The dimensions and characteristics of greenhouse are given in Table (1).

Table (1): Dimensions and characteristics of greenhouse

\begin{tabular}{|c|c|}
\hline Specifications & Greenhouse \\
\hline - Tunnel design & Quoin-set design \\
\hline - Covering material & Plastic film from polyethylene \\
\hline - Tunnel size & Large \\
\hline - Length, m & 60 \\
\hline - Width, m & 8.5 \\
\hline - Height, $\mathrm{m}$ & 3.25 \\
\hline - Active width, $\mathrm{m}$ & 5.5 \\
\hline - Crop support height, $\mathrm{m}$ & 2.0 \\
\hline - $\quad$ Total ground area, $\mathrm{m}^{2}$ & 510 \\
\hline
\end{tabular}

\section{Experimental procedures:}

The experiments were carried out in order to choose proper application under local green house conditions. Cucumber greenhouse in ElGemmieza Agriculture Research Station, El-Gharbia governorate was divided into three plots to serve as replicates. Treatments compared were: spinning disc atomizer before and after development, motorized knapsack blower sprayer and hydraulic sprayer. These sprayers were operated at traveling speed of $0.6 \mathrm{~m} / \mathrm{s}$. The control area toke the same procedure but without treatment of fungicide.

Cucumber leaves were randomly collected from each subplot, the infection on each leaf was evaluated using the following index: 
Table (2): Downy mildew infection on cucumber leaves and equivalent numerical values

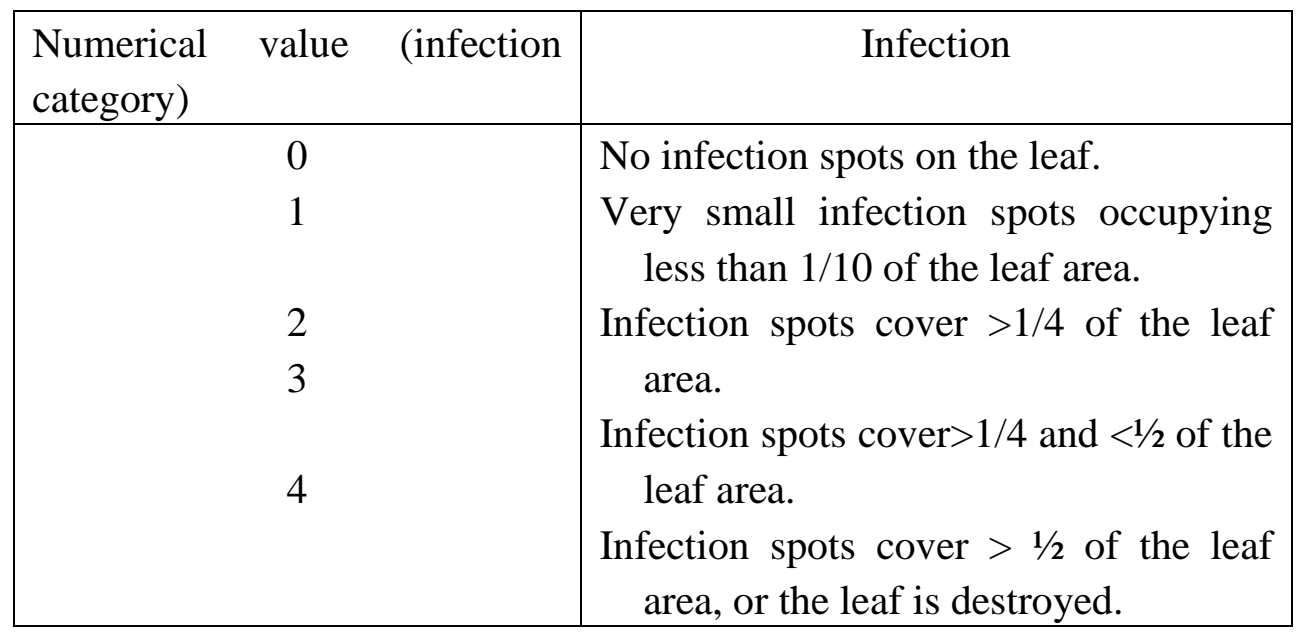

- Disease severity was calculated using the equation developed by Townsend and Heuberger, (1943).

$$
\mathrm{P}=[\Sigma(\mathrm{n} \times \mathrm{v}) / 4 \mathrm{~N}] \times 100
$$

Where:-

$$
\begin{array}{ll}
\mathrm{P} & =\text { Disease degree. } \\
\mathrm{n} & \quad \text { =Number of leaves within infection category. } \\
\mathrm{v} & \quad \text { =Numerical value of each category. } \\
\mathrm{N} & \quad \text { = Total number of leaves. }
\end{array}
$$

- Fungicide efficacy (FE) was calculated using equation (Fröhlich, 1979)

$$
\begin{array}{cl}
\mathrm{FE}=[\mathrm{C}-\mathrm{T} / \mathrm{C}] \times 100 \\
\mathrm{C} & \text { Disease severity in Control. } \\
\mathrm{T} & \text { Disease severity in treatment. }
\end{array}
$$

- Foliage coverage efficiency of each applicator was determined by measuring the spray deposits in two directions, horizontally on both sides of the spray axis, and vertically on three levels of the plant as follows: 


\section{a. Horizontal coverage:}

The method was described by El-Gendy. (1994). Strips of polyethylene sheets $(5 \times 10 \mathrm{~cm})$ were distributed on the field soil one meter on both side of the spray axis in distance of $25 \mathrm{~cm}$ from each other. Methyl blue solution $(0.25 \%)$ was applied instead of the fungicide using the four applicators. After drying, the strips were collected and the indicator was resolved in known amount of distilled water and the amount of the dye on each distance was assessed by spectrophotometer wavelength $(340 \mathrm{~nm})$.

b. Vertical coverage:

Distributions of the spray suspension and mean spray droplet diameter were estimated on water sensitive papers hung on three levels on the plants representing the lower, middle leaves and on plant tops. Water sensitive paper cards were fixed on plants at straight radial lines on each level.

- The droplets fungicides using the different applicator types after the plant got dry, the cards were collected, the spray droplets were counted per square centimeter $\left(\mathrm{No} / \mathrm{cm}^{2}\right)$, the volume median diameter (VMD) of each sprayer was calculated according to the following formula (Awady, 1977 and 2003):

$$
\left[\mathrm{VMD}=\left[\sum_{\mathrm{i}=1}^{\mathrm{i}=\mathrm{n}} \mathrm{n}_{\mathrm{i}} \mathrm{X}_{\mathrm{i}}^{3} \div \sum_{\mathrm{i}=1}^{\mathrm{i}=\mathrm{n}} \mathrm{n}_{\mathrm{i}}\right]^{1 / 3}\right]
$$

Where:-

$$
\begin{array}{ll}
\mathrm{n}_{\mathrm{i}} & \begin{array}{l}
\text { S Summation of number of droplets at each } \\
\text { classification of droplet size class; }
\end{array} \\
\mathrm{X}_{\mathrm{i}} & =\text { Droplet diameter for the given class. }
\end{array}
$$

- The velocity of the air stream at the modified disc, measured with an anemometer was $3.5 \mathrm{~m} / \mathrm{s}$.

- The flow rate was calculated to determine nozzle discharge during operation for one minute. Then the graduate cylinder was used to calibrate the discharge.

- A spectrophotometer was used to measure the spray deposition on plant leaves. 
- Percentage of damage plant (Dp\%) was estimated as follows:-

$$
\mathrm{Dp} \%=\mathrm{a} / \mathrm{b} \times 100
$$

Where:-

$$
\begin{array}{ll}
\mathrm{Dp} \% & =\text { Percentage of damaged plants; } \\
\mathrm{a} & =\text { Number of damaged plants; } \\
\mathrm{b} & =\text { Total numbers of plants at the same } \\
& \text { deduced area. }
\end{array}
$$

\section{RESULTS AND DISCUSSIONS}

Performance of modified sprayer included the different factors related to average deposited droplets $/ \mathrm{cm}^{2}$, droplet size expressed in Volume Mean Diameter (V.M.D.), distribution uniformity.

\section{Number of droplets $/ \mathrm{cm}^{2}:-$}

The observations reported in Fig. (2) show the effect of spread type on distribution of spray deposits across the swath (droplets $/ \mathrm{cm}^{2}$ ) on cucumber plant. It is clear that, for all spray types, the number of droplets decreased as the distance between the strips and spray axis increased on the both sides. The obtained results indicated that the modified disc sprayer performed the highest number of droplets (224 droplets). Meanwhile, lowest number of droplets (43 droplets) was gained using hydraulic sprayer (gun).

The indicator distribution carve in case of modified disc sprayer was sharp in contrast of other sprayers which produced wide carves. Thus, Appling modified sprayer concentrate the fungicides on the plant foliage and decrease the fungicide amount lost on the soil between the rows. In general, this data was in agreement with those obtained by Moustafa $e t$ al. (2003).

The estimated mean number of droplets $/ \mathrm{cm}^{2}$ was higher with $81 \%, 71 \%$ and $46 \%$ by using modified disc sprayer, conventional disc sprayer and motorized knapsack blower sprayer respectively than number of droplets obtained by hydraulic sprayer (gun). 


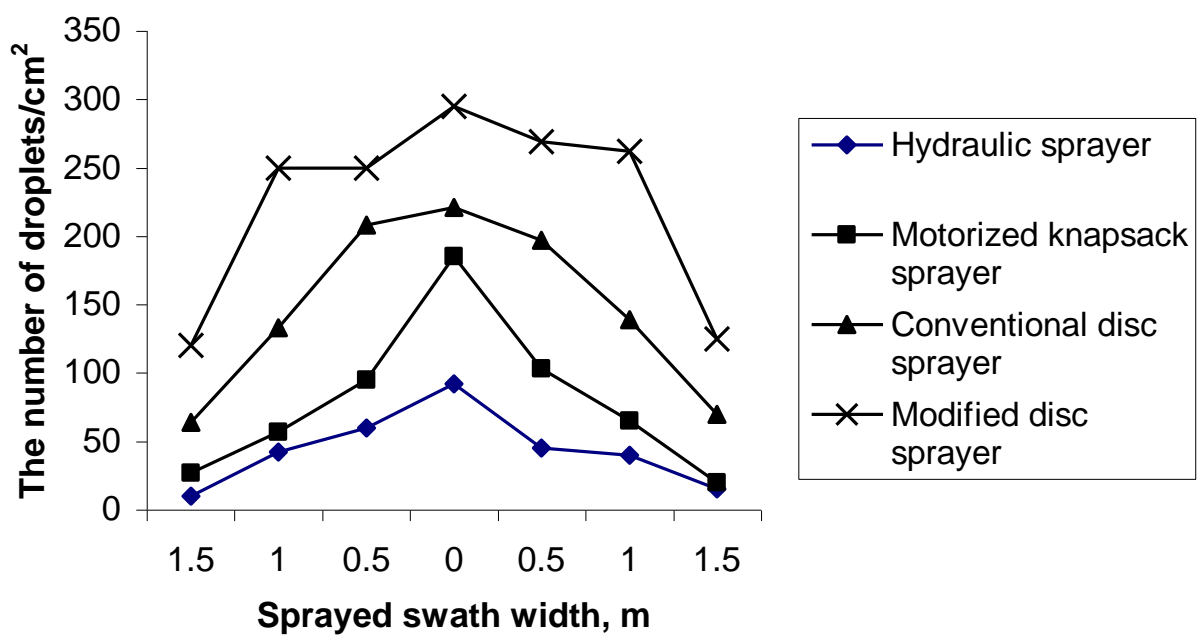

Fig. (2): Spray distribution across the swath (droplets $/ \mathrm{cm}^{2}$ ) at three levels of plant (Top, Middle and Bottom).

\section{The volume median diameter (VMD):-}

From the obtained data, presented in Table (3) it is remarkable that, the volume median diameter (VMD) of the different tested applicators was greatly affected with the fungicides suspension amount per fed. The droplet development spinning disc sprayer produced very small droplets $(65 \mu \mathrm{m})$. The spinning disc sprayer before development produced small droplets $(95 \mu \mathrm{m})$. The motorized knapsack sprayer produced medium droplets $(151 \mu \mathrm{m})$, while the hydraulic sprayer produced relatively large droplets $(228 \mu \mathrm{m})$.

\section{Plant damage:-}

The results illustrated in Table (3) indicated that, the hydraulic sprayer resulted in higher value of plant damage $(6.73 \%)$ than the other sprayers. This higher value of plant damage resulted from hydraulic sprayer because of the higher impact action on the plant branches and leafs, due to big size of droplets, and higher amount of fungicide suspension applied (400 L/fed) compared with others tested sprayers. The percentages of plant damage were $5.32 \%, 1.53 \%$ and $1.26 \%$ when using knapsack sprayer, disc sprayer before development and disc sprayer after development, respectively. 
Table (3): The field performance characteristics of different sprayer

\begin{tabular}{|c|c|c|c|c|c|}
\hline $\begin{array}{c}\text { Sprayer } \\
\text { Type }\end{array}$ & $\begin{array}{c}\text { Mean } \\
\text { number of } \\
\text { droplets/cm }\end{array}$ & $\begin{array}{c}\text { Droplet } \\
\text { size } \\
(\mathrm{VMD}), \\
\mu \mathrm{m}\end{array}$ & $\begin{array}{c}\text { Plant } \\
\text { Damage, } \%\end{array}$ & $\begin{array}{c}\text { Fungicide } \\
\text { Efficiency, } \\
\%\end{array}$ & $\begin{array}{c}\text { Disease } \\
\text { incidence, } \\
\%\end{array}$ \\
\hline $\begin{array}{c}\text { Modified } \\
\text { disc }\end{array}$ & 224 & 65.0 & 1.26 & 86.33 & 8.52 \\
\hline $\begin{array}{c}\text { Conventional } \\
\text { disc }\end{array}$ & 147 & 95.0 & 1.53 & 73.45 & 16.55 \\
\hline $\begin{array}{c}\text { Motorized } \\
\text { knapsack }\end{array}$ & 79 & 151 & 5.32 & 69.26 & 19.17 \\
\hline Hydraulic & 43 & 228 & 6.73 & 61.59 & 23.95 \\
\hline Control & - & - & - & - & 62.35 \\
\hline
\end{tabular}

\section{Fungicide efficiency: (FE):-}

Evaluation of four applicator types for their effect on fungicide efficiency in controlling downy mildew disease on cucumber indicated that all the tested sprayers showed sufficient disease control. It is shown from the obtained data presented in Fig. (3), that the arrangement of different tested sprayers according to fungicides efficiency is found to be in the following descending order: disc sprayer after development $>$ disc sprayer before development $>$ motorized knapsack sprayer $>$ hydraulic sprayer.

The spinning disc sprayer after development showed the highest fungicides efficiency (86.33\%) compared with the other applicators. This obtained data can be explained, since in combining the very small volume and high number of the spray droplets with air-assistance produced by spinning disc sprayer after development, spray bounce and run off from foliage are reduced, as well as better fungicides coverage and good impaction efficiency of spray, which enhanced the fungicides efficiency. In contrast, others applicators produced relatively little number of large droplets with a large inter space, which in turn resulted in bad coverage with the fungicide and bad control efficiency 


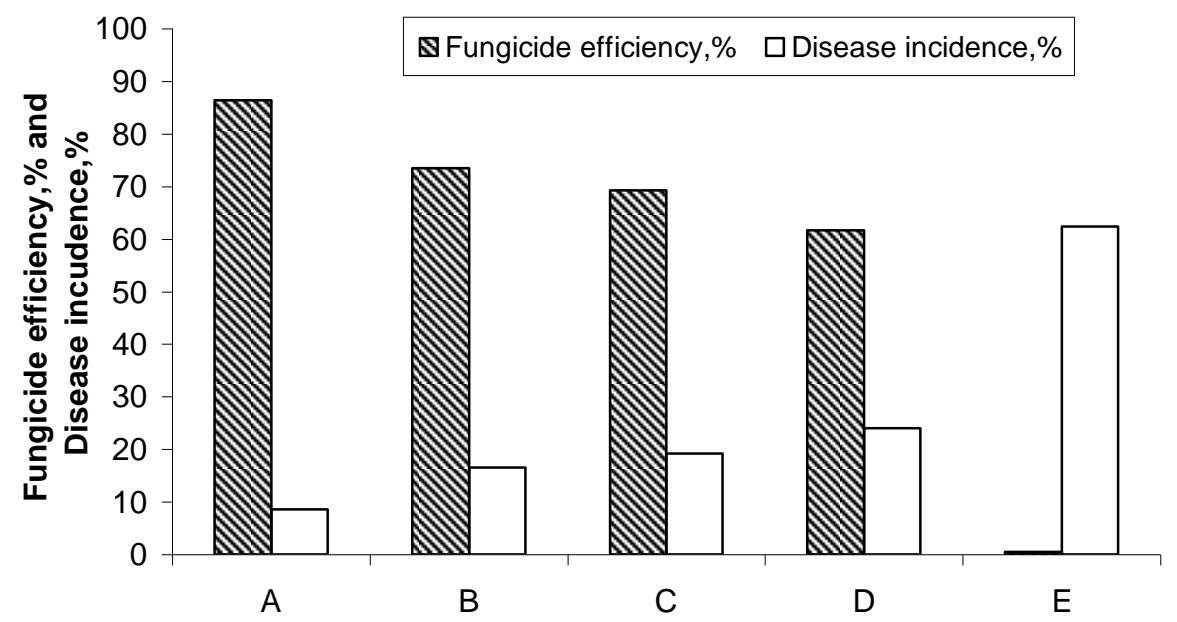

Where:-
A: Modified disc sprayer.
B: Conventional disc sprayer.
C: Motorized knapsack sprayer.
D: Hydraulic sprayer (gun).
E: Control.

Fig. (3): Effect of sprayer type on disease incidence and fungicide efficiency used to control downy mildew disease on cucumber plants in greenhouse

\section{CONCLUSION}

It can be concluded that the spinning disc sprayer after development (combining very small volume and high number of the spray droplets with air-assistance) is the most suitable applicator to control disease plant under local greenhouse conditions, where it gives the best result of volume median diameter VMD $(65 \mu \mathrm{m})$, mean number ofdroplets $/ \mathrm{cm}^{2}$ (295), and fungicide efficiency of (86.33\%), compared with the other sprayers.

\section{REFERENCES}

Abdel-Fattah, A.A (2003). Comparative study of different pest control machinery including drift-spray equipment for crops, Ph.D Thesis, Agric. Eng. Dept., Fac. of Agric., Al-Azhar Univ.: 118.

Awady, M.N. and F.A. Afifi. (1976). Spray-residues examination for equipment used in control of cotton pests. An. Agric. Sci., Ain Shams Univ., zl(12):73-85. 
Awady, M.N. (1977 and 2003). Engineering of spraying and application of field materials. [in Arabic]. Text book. Fac. of Agric., Ain Shams Univ.:107.

El-Aidy, F. (1991). Low cost plastics greenhouse suited to the climatic conditions in North of Delta, Egypt. "Plasticulture" n 92-1991/4 p:3340.

El-Ashry, A.S. (1994). Proper size of tractor in local greenhouse. M.Sc. Fac. of Agric., Kafr El-Sheikh, Tanta Univ..

El-Gendy, H.A. (1994). A study on the operation of an Ultra-low-volume sprayer by solar photovoltaic cells. M. Sc. Th. Fac. of Agric., Ain Shames Univ..

Fröhlich, G (1979). Phytopathologia und Pflanzenschutz. Veb Gusty Fisher Verlag, Jena:295 pp.

Ismail, A.A. and S.E. Badr (2004). Effect of some applicator types on metalaxyl residue in cucumber with special reference to its toxicological effects. Minufiya J. Agric. Res. Vol.(2) No 29: 557-568.

Kepner, R.A. and E.L. Barger (1982). Pricepales of farm machinery. AVI. Pub. Company, Inc. West Part Conn. :282-311.

Matthews, G.A. (1992). Pesticide application methods, $2^{\text {nd }}$ ed., Longman, Scientific \& Technical, London: 405.

Moustafa, M.S.H.; A.A. Ismail and H.A. El-Gendy (2003). Effect of applicator types on the efficacy of fungicides and their role in environmental pollution. The XI Conf. of the Egyptian Agric. Eng. Soc., held in 15 - 16 October 2003.

Moustafa, M.S.H. and A.A. Ismail (2003). Effect of fungicide applicator types on the efficacy of fungicides used for control late blight of potato. J. Agric. Res. Tanta Univ. 29(3):568-576.

Roman, H. and G.D. Baerdemaeker (1995). Using principal gains for evaluating and optimizing the performance of sprays. Trans. ASAE, 38(5): $1327-1333$.

Towsend, G.K. and T. W. Heu barger (1943). Methods for estimating loses caused by diseases experiments. Plant Dis. Rept. 27:340 - 343. 
الملخص العربى

\section{تطوير وتقييم أداء آله لرش المبيدات داخل الصوب الزراعية}

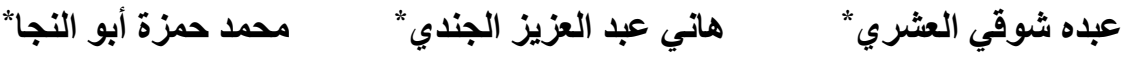

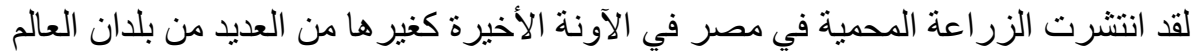

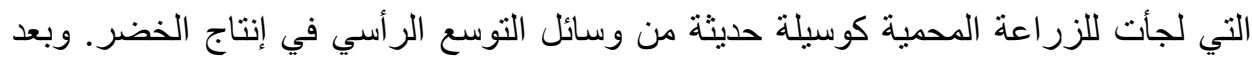

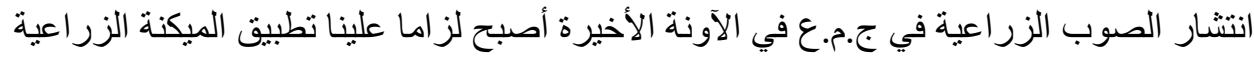

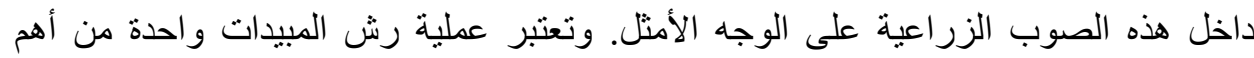

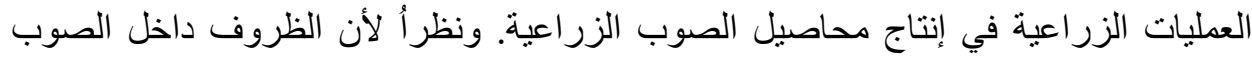

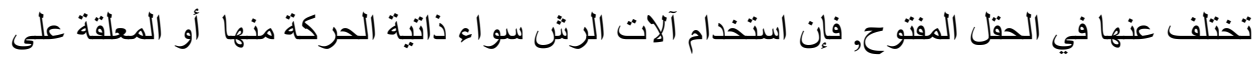

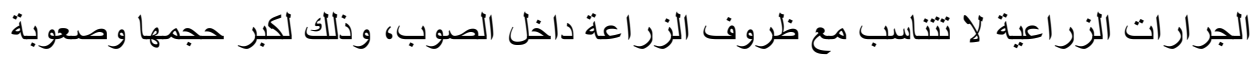

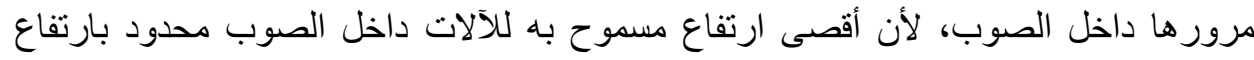

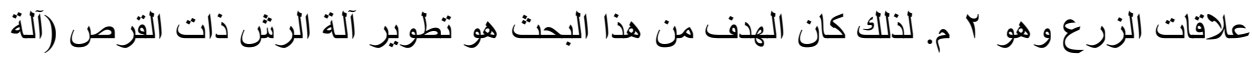

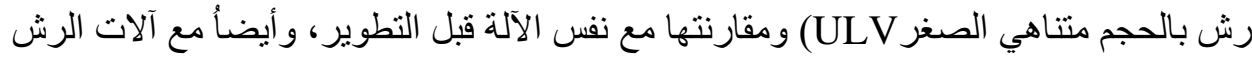
المختلفة والتي تختلف فيما بينها في حجم قطيرات محلول الرش (رشاشة الظهر ذات ذات الهواء الحامل LV- وموتور الرش الأرضي . .7 لتر HV ) ) ، وتحديد الآلة الأكثر ملائمة لهذه فئه

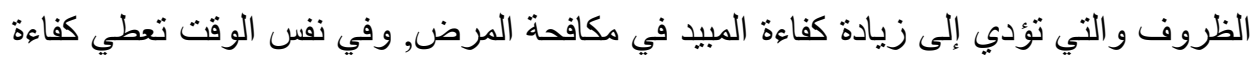

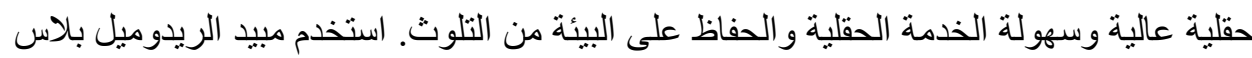
بتركيز • 10 جم/ . . التزر ماء لمكافحة مرض البياض الزغبي على نباتات الخيار ذات ارتفاع

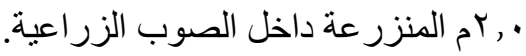
وكانت أهم النتائج المتحصل داجل عليها كما يلي:- ـ - استخدام آلة الرش ذات القرص الدوار بعد التعديل أدت تركيز المحلول على النباتات المعاملة وتقليل تلوث التربة بالمبيدات.

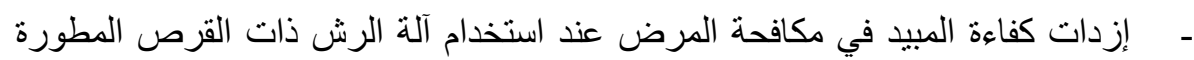

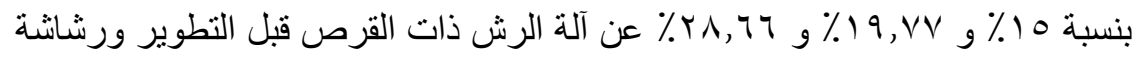

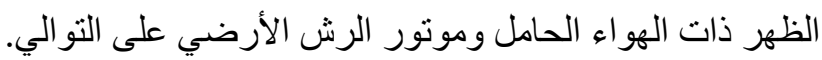

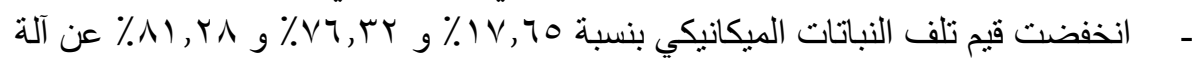
الرش ذات القرص قبل التطوير ورشاشة الظهر ذات الهواء الحامل وموتور الرش الأرضي على التوالي.

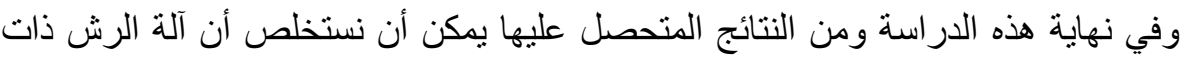

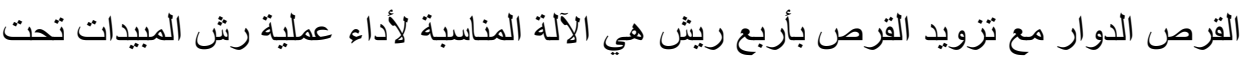

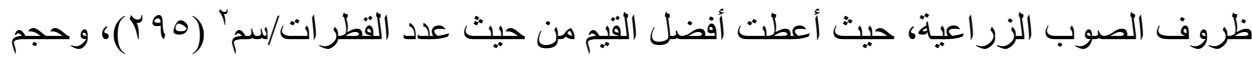

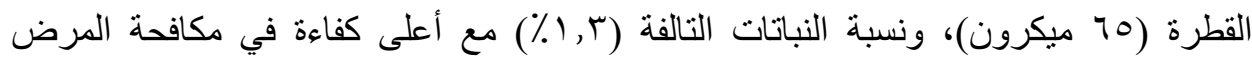
.(\% \% (

* باحث أول بقسم بحوث ميكنة المحاصيل الحقلية والبستانية بمعهد بحوث الهندسو الزر اعية. 